\title{
Two patients with marginal symptoms showing hyperthecosis at the edge of malignancy: Presentation of two cases
}

\author{
Iki farklı semptom ve malignensi riski ile yanslyan hipertekozis. iki vaka sunumu
}

\author{
Sinan Beksac ${ }^{1}$, Ilker Selçuk', Gökhan Boyraz', Güneş Güner², Mert Turgal' ${ }^{1}$, Alp Usubutun ${ }^{2}$ \\ 'Department of Obstetrics and Gynecology, Faculty of Medicine, Hacettepe University, Ankara, Turkey \\ ${ }^{2}$ Department of Pathology, Faculty of Medicine, Hacettepe University, Ankara, Turkey
}

\section{Abstract}

It is important to define the aetiology of increased levels of androgens in women. Ovarian stromal hyperplasia ( $\mathrm{OSH}$ ) and ovarian hyperthecosis (OHT) are non-neoplastic pathologies. They show the excess of androgen production and have a wide clinical range like hirsutism, virilisation, abnormal menses, obesity, hypertension and insulin resistance. Ovarian stromal hyperplasia and hyperthecosis are commonly seen in postmenopausal women and generally involve both ovaries. Laboratory testing is the gateway; testosterone and dehydroepiandrosterone sulphate (DHEA-S) are the first hormones that should be measured. $\mathrm{OSH}$ and OHT could also be a reason for endometrial malignancy by unopposed oestrogenic status. Hyperthecosis must be differentiated from several other diseases, especially malignant conditions, and the treatment for postmenopausal women should be bilateral oophorectomy. (J Turkish-German Gynecol Assoc 2013; 14: 182-5)

Key words: Hyperthecosis, hirsutism, menopause, malignancy

Received: 13 December, 2012

Accepted: 02 January, 2013

\section{Özet}

Bayanlarda artmış androjen seviyelerinin etyolojisini açılamak önemlidir. Overyan stromal hiperplazi (OSH) ve overyan hipertekozis (OHT) neoplastik olmayan patolojilerdir ve artmış androjen üretimini gösterirler. Hirsutizm, virilizasyon, menstrüel düzensizlik, obezite, hipertansiyon ve insülin rezistansı geniş klinik spektrumun parçalanıdır. Overyan stromal hiperplazi ve hipertekozis genellikle postmenopozal bayanlarda görülür ve sıklıkla her iki overi de içerir. Laboratuvar testleri tanıda anahattır; testosteron ve dehidroepiandrosteron sülfat (DHEA-S) bakılacak ilk hormonal testlerdir. OSH ve OHT, endometrial malignensi açısından karşlanmamış östrojen üretimi nedeniyle risk oluşturur. Hipertekozis diğer birçok hastalıktan ve özellikle malign durumlardan aynılmalıdır ve postmenopozal bayanlarda bilateral ooferektomi tedavi için önemlidir. (J Turkish-German Gynecol Assoc 2013; 14: 182-5)

Anahtar kelimeler: Hipertekozis, hirsutizm, menopoz, malignensi

Geliş Tarihi: 13 Aralık 2012

Kabul Tarihi: 02 Ocak 2013

Çevrimiçi Yayın Tarihi: 10 Temmuz 2013

\section{Introduction}

It is important to define the aetiology of increased levels of androgens in women because of the possibility of malignancy originating from the ovaries or adrenal gland. Ovarian stromal hyperplasia (OSH) and ovarian hyperthecosis (OHT) are both similar and non-neoplastic pathologies. Stromal hyperplasia is the nodular or diffuse proliferation of the ovarian stroma, whereas ovarian hyperthecosis is stromal proliferation accompanied by luteinised stromal cells. They both show an excess of androgen production and have a wide clinical range, including hirsutism, virilisation, abnormal menses, obesity, hypertension and insulin resistance (1). This androgenic process leads to an elevation of testosterone. Additionally, by peripheral aromatisa- tion of androgenic hormones, an increase in oestrogenic hormones occurs (2).

$\mathrm{OSH}$ and OHT with increased hormonal states were considered to be an aetiological database for endometrial cancer in a few case reports (3). The prevalence of this disease is unknown as most of the information about the disease has been derived from case reports. Here, we describe two cases of ovarian stromal hyperthecosis with different symptoms.

\section{Case Reports}

\section{Case 1}

A 59-year-old multiparous woman presented with a one year history of progressive hirsutism, acne and hair loss. 
She had her menarche when she was 14 years old and had normal periods since then until menopause (at the age of 51). She was hypertensive and also had an insulin resistance syndrome with hyperthyroidism. Initial investigations revealed significantly elevated androgen levels. The serum concentration of testosterone was $195 \mathrm{ng} / \mathrm{dL}$, dehydroepiandrosterone sulphate (DHEA-S) was $88.9 \mu \mathrm{g} / \mathrm{dL}$ and cortisol was $30 \mu \mathrm{g} / \mathrm{dL}$. Other laboratory parameters were normal. Sonography showed bilaterally enlarged ovaries with no other signs. Total abdominal hysterectomy and bilateral salpingooophorectomy was performed with frozen section analysis because of the risk of malignancy and the final pathology result revealed stromal hyperthecosis for bilateral ovaries (Figure 1a, 1b and 1c show the pathology images of hyperthecosis for this patient). After surgery, the symptoms of the patient reduced over time, and improvements in laboratory results were obtained.

\section{Case 2}

A 55-year-old multiparous woman presented with postmenopausal bleeding. She did not have any other symptoms; no hirsutism, no acne or hair loss. Her physical examination was normal and she had been in menopause from the age of 50 years. She had abdominal obesity, hypertension and hypothyroidism. Her laboratory findings showed levels of testosterone, oestradiol and Follicle stimulating hormone (FSH): $105 \mathrm{ng} / \mathrm{dL}$, $27 \mathrm{pg} / \mathrm{mL}$ and $75 \mathrm{mIU} / \mathrm{mL}$, respectively. The sonograph showed an endometrial thickness of $10 \mathrm{~mm}$ with ovaries that were slightly echogenic, but there was no solid cystic lesion visible on the ovaries. An endometrial sampling operation was per-
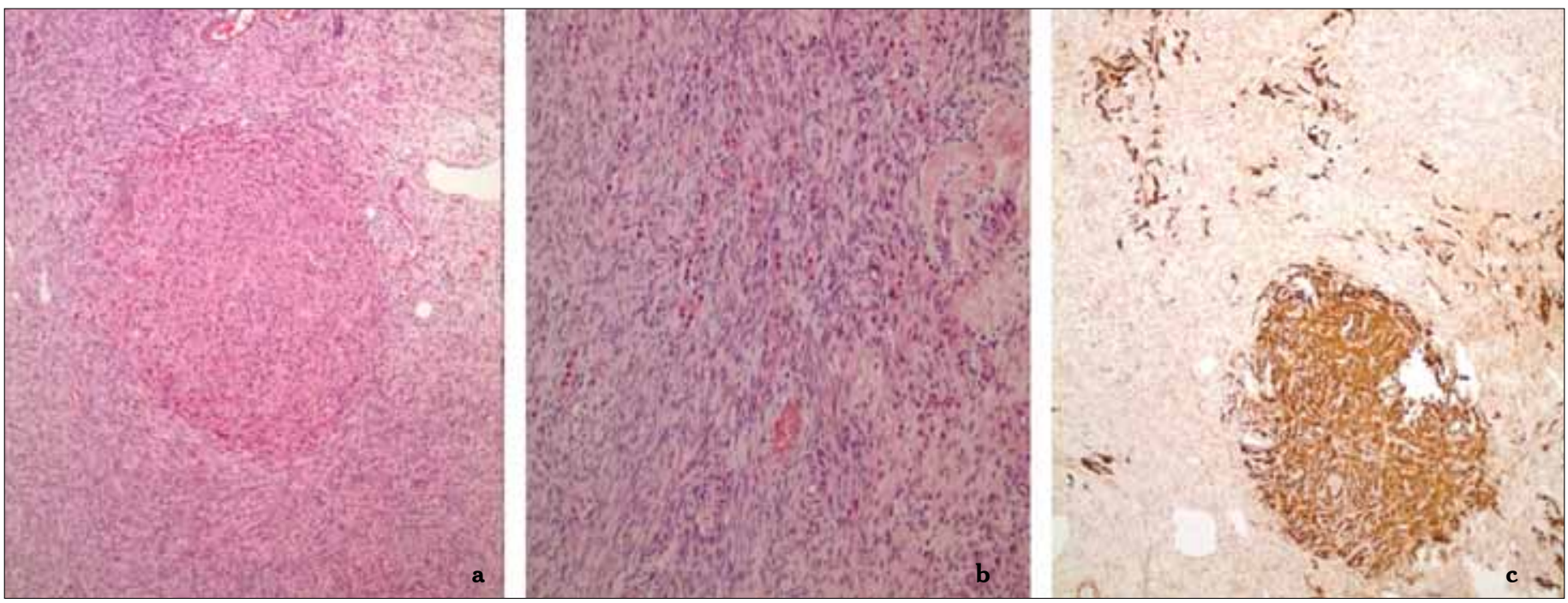

Figure 1. A nodule made up of eosinophilic, luteinised theca cells was seen in the ovarian stroma (Figure 1a). As well as forming nodules, these cells were diffusely dispersed into the stroma (Figure 1b). The same nodule and the other theca cells dispersed in the stroma displayed strong calretinin positivity immunohistochemically (Figure 1c) (x10, calretinin staining)

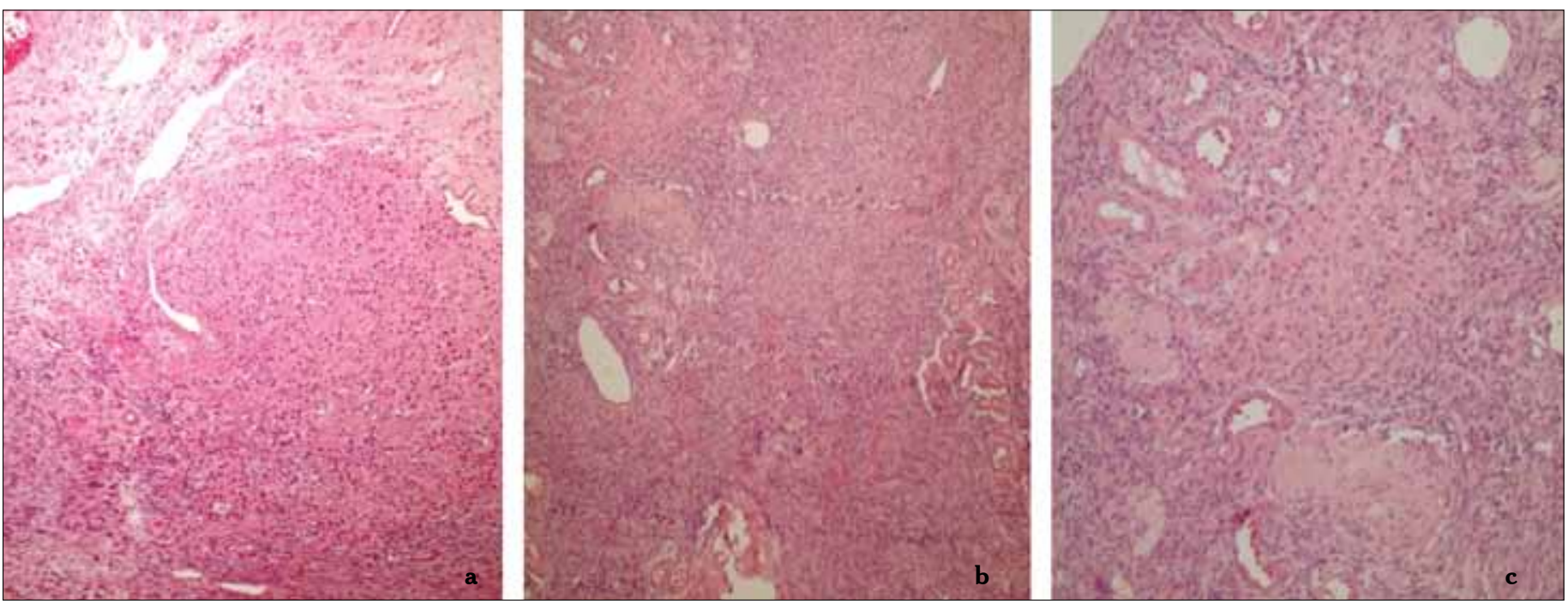

Figure 2. The ovarian stroma displayed vaguely nodular (Figure 2a) or diffusely dispersed (Figures 2b, 2c) cells with eosinophilic cytoplasm and indistinct cell borders (H\&E) 
formed and the pathology result revealed endometrial intraepithelial neoplasia (EIN). Total abdominal hysterectomy and bilateral salpingooophorectomy was performed with frozen section analysis and the final pathology result revealed stromal hyperthecosis for bilateral ovaries (Figure 2a, 2b and 2c show the pathology images of hyperthecosis for case 2 ).

\section{Discussion}

Ovarian hyperthecosis and polycystic ovary syndrome (PCOS) have similar presentations, making it difficult to distinguish between these two diseases. Symptoms of hyperandrogenism for ovarian hyperthecosis continue beyond the menopause, and the major cause of hyperandrogenemia cases in menopause is ovarian hyperthecosis. Women of this pathology present with severe hirsutism and other clinical evidence of virilisation that are not seen in PCOS, such as cliteromegaly, temporal balding, voice changes and diffuse acne (4).

In 1982, Hugheston suggested that hyperthecosis is a severe form of PCOS (5). Hyperthecosis is rarely seen in young women and is generally encountered in menopausal women (6). A complete medical history and full physical examination for virilisation, acne, abdominal obesity, hair loss, menstrual regularity, timing of menopause, and the duration of symptoms are all needed, as all are important hallmarks of diagnosis. The first patient had severe hirsutism, acne and hair loss, whereas the second patient did not have any of these symptoms.

Laboratory testing is the gateway for diagnosis; testosterone and dehydroepiandrosterone sulphate (DHEA-S) are the first hormones to be measured (7). Testosterone levels may be as high as in androgen secreting tumours (200ng/dL). Generally, testosterone levels are not as high as expected, but are nearly always above the postmenopausal range and are higher than the levels observed in PCOS (6). If the serum total testosterone level is $>150 \mathrm{ng} / \mathrm{dL}$, imaging of the adrenal glands and ovaries must be performed, because high levels of testosterone is the single most important laboratory finding (8). In both of the cases described here, the testosterone levels were elevated, so sonographic evaluation was performed for the identification of the underlying cause.

Ovarian stromal hyperplasia and hyperthecosis are commonly seen in postmenopausal women and generally involve both ovaries (9). To evaluate the ovaries, a pelvic ultrasound or magnetic resonance imaging may be predictive and helpful for defining pathologies and excluding malignant conditions in women with elevated testosterone levels. A computed tomography or magnetic resonance imaging of the adrenals is important for women with high levels of DHEA-S (10). In contrast to the knowledge that isolated testosterone elevation is related to ovarian pathology, rare cases of testosterone-secreting adrenal tumours have also been described in the literature (11). DHEA-S levels were normal for the two patients reported here.

In severe hyperthecosis, ultrasonography shows bilateral expansion in the ovarian stroma; ovaries appear more solid, and a few cysts may also be seen (9). Ovarian size is also frequently increased in postmenopausal women with hyperthecosis (12). Insulin resistance is present in almost all cases and the risk of type 2 diabetes and cardiovascular diseases increase. Additional findings like obesity and skin tags may also be seen (4). The first patient had bilateral enlarged ovaries, insulin resistance, and obesity, as described in the literature. The second patient had no symptoms other than postmenopausal bleeding. Her sonographic evaluation showed only echogenic ovaries. Increases in oestrogen production by androgens secreted on the ovaries result in an increased risk of endometrial hyperplasia and endometrial carcinoma, especially in postmenopausal women (13). Our second patient had an endometrial intraepithelial neoplasia resulting from endometrial biopsy. Hyperthecosis must be differentiated from several other diseases, especially malignant conditions. Treatment should be bilateral oophorectomy for postmenopausal women (14). However, if the patient has multiple comorbidities, then longterm GnRH agonist treatment may be an option in cases where malignancy is excluded (15). For premenopausal women, treatment should be the same as for PCOS in cases where malignancy is excluded (7).

In conclusion, effective and timely treatment, especially bilateral oophorectomy in postmenopausal women, can reverse the cardio-metabolic consequences of hyperandrogenemia, and can reveal symptoms like acne and hair loss; also the risk of endometrial cancer is reduced.

\section{Ethics Committee Approval: N/A}

Informed Consent: Written informed consent was obtained from patients who participated in this study.

Peer-review: Externally peer-reviewed.

Author contributions: Concept - S.B., A.U.; Design - S.B., A.U.; Supervision - S.B.; Resource - S.B.; Materials - I.S., G.B., G.G., M.T.; Data Collection\&/or Processing - I.S., G.B., M.T.; Analysis\&/ or Interpretation - S.B., A.U.; Literature Search - I.S., G.B., M.T.; Writing - S.B., I.S., G.B., G.G., M.T., A.U.; Critical Reviews - S.B.

Conflict of Interest: No conflict of interest was declared by the authors.

Financial Disclosure: No financial disclosure was declared by the authors.

\section{References}

1. Abuladze MV, Sharabidze NG. Clinical, hormonal and histological features in ovarian stromal hyperthecosis. Georgian Med News 2006; 50-3.

2. Aiman J, Edman CD, Worley RJ, Vellios F, MacDonald PC. Androgen and estrogen formation in women with ovarian hyperthecosis. Obstet Gynecol 1978; 51: 1-9.

3. Kuntscherová J, Michal M, Nováková R, Jahnová H. Ovarian stromal hyperthecosis and concurrent endometrial carcinoma of the uterus. Ceska Gynekol 2000; 65: 94-7.

4. Barth JH, Jenkins M, Belchetz PE. Ovarian hyperthecosis, diabetes and hirsuties in post-menopausal women. Clin Endocrinol (Oxf) 1997; 46: 123-8. [CrossRef]

5. Hughesdon PE. Morphology and morphogenesis of the SteinLeventhal ovary and of so-called "hyperthecosis". Obstet Gynecol Surv 1982; 37: 59-77. [CrossRef] 
6. Nagamani M. Polycystic ovary syndrome variants: hyperthecosis. In Reproductive Endocrinology, Surgery, and Technology, Adashi EY (ed.). Lippincott-Raven: Philadelphia, PA, 1996; 1257-69.

7. Martin KA, Chang RJ, Ehrmann DA, Ibanez L, Lobo RA, Rosenfield $\mathrm{RL}$, et al. Evaluation and treatment of hirsutism in premenopausal women: an endocrine society clinical practice guideline. J Clin Endocrinol Metab 2008; 93: 1105-20. [CrossRef]

8. Friedman CI, Schmidt GE, Kim MH, Powell J. Serum testosterone concentrations in the evaluation of androgen-producing tumors. Am J Obstet Gynecol 1985; 153: 44-9.

9. Rousset P, Gompel A, Christin-Maitre S, Pugeat M, Hugol D, Ghossain MA, et al. Ovarian hyperthecosis on grayscale and color Doppler ultrasound. Ultrasound Obstet Gynecol 2008; 32: 694-9. [CrossRef]

10. Rothman MS, Wierman ME. How should postmenopausal androgen excess be evaluated? Clin Endocrinol (Oxf) 2011; 75: 160-4. [CrossRef]
11. Cordera F, Grant C, van Heerden J, Thompson G, Young W. Androgen-secreting adrenal tumors. Surgery 2003; 134: 874-80. [CrossRef]

12. Bühler-Christen A, Tischler V, Diener PA, Brändle M. New onset alopecia and hirsutism in a postmenopausal women. Gynecol Endocrinol 2009; 25: 324-7. [CrossRef]

13. Nagamani M, Hannigan EV, Dinh TV, Stuart CA. Hyperinsulinemia and stromal luteinization of the ovaries in postmenopausal women with endometrial cancer. J Clin Endocrinol Metab 1988; 67: 144-8. [CrossRef]

14. van Heyningen C, MacFarlane IA, Diver MJ, Muronda C, Tuffnell D. Virilization due to ovarian hyperthecosis in a postmenopausal woman. Gynecol Endocrinol 1988; 2: 331-8. [CrossRef]

15. Vollaard ES, van Beek AP, Verburg FA, Roos A, Land JA. Gonadotropin-releasing hormone agonist treatment in postmenopausal women with hyperandrogenism of ovarian origin. $\mathrm{J}$ Clin Endocrinol Metab 2011; 96: 1197-201. [CrossRef] 